\title{
Potensi Pemulihan Pariwisata Halal di Ponorogo (Analisa Strategi Pada Masa Pandemi Covid-19)
}

\author{
Rizqi Rahmawati, Kaukabilla Alya Parangu
}

\author{
Universitas Merdeka Ponorogo, Institut Agama Islam Negeri Ponorogo, Indonesia \\ rizqi.rahma@gmail.com, kaukabilla@iainponorogo.ac.id
}

\begin{abstract}
Abstrak: Pandemi Covid-19 mempunyai dampak yang cukup besar pada segala sektor, dan pariwisata halal merupakan sektor yang juga cukup merasakan dampaknya. Penelitian ini menggali potensi upaya pemulihan pariwisata halal dengan pendekatan analisa deskriptif. Menggunakan data terbaru tahun 2020 dan tema yang unik. Metode penelitian menggunakan pendekatan analisa deskriptif, dengan teknik pengumpulan data menggunakan triangulasi berupa observasi, wawancara dan dokumentasi. Berdasarkan penggolahan data diperoleh hasil dari strategi dengan melakukan Protokol kesehatan berbasis CHSE yaitu Cleanliness (Kebersihan), Health (Kesehatan), Safety (Keamanan), dan Enviroment (Ramah lingkungan) dan juga startegi pemulihan dengan jangka pendek, menengah dan panjang. Strategi jangka pendek lebih mengedepankan dukungan pemerintah daerah, mulai dukungan finansial dan kebijakan yang mendukung. Strategi menengah yaitu dengan menggabungkan peran lembaga pendidikan, pemerintah dan media. Strategi jangka panjang dengan melakukan sistem opersional industri pariwisata, dengan input yaitu memperhatikan kualitas destinasi pariwisata, dan kemudian diprosesnya dengan bantuan penuh pihak pemerintah dan outputnya melakukan pembenahan yang tersturuktur sehingga pariwisata halal di ponorogo dapat perkembang lagi. Dari hasil diatas diperoleh kesimpulan bahwa Pariwisata Halal di Ponorogo telah melakukan pembenahan dengan strategi-setrategi diatas, namun masih belum maksimal sehingga perlu didukung secara penuh oleh Pemerintah daerah, Stakeholder, Media dan Masyarakat.
\end{abstract}

Kata Kunci: pariwisata halal, CHSE, pandemi, Covid-19

\begin{abstract}
The Covid-19 pandemic has had a considerable impact on all sectors, and halal tourism is a sector that is also quite affected. This study explores the potential of halal tourism recovery efforts with a descriptive analysis approach. Using the latest data for 2020 and a unique theme. The research method uses a descriptive analysis approach, with data collection techniques using triangulation in the form of observation, interviews and documentation. Based on data processing, the results obtained from the strategy by carrying out a CHSE-based health protocol, namely Cleanliness, Health, Safety, and Environment, as well as recovery strategies in the short, medium and long term. The short-term strategy prioritizes local government support, start with financial support and supportive policies. The intermediate strategy is to combine the roles of educational institutions, the government and the media. The long-term strategy is to carry out an operational system for the tourism industry, with input, namely paying attention to the quality of tourism destinations, and then processing it with the full assistance of the government and the output carrying out structured improvements so that halal tourism in Ponorogo can develop again. From the results above, it can be concluded that Halal Tourism in Ponorogo has made improvements with the strategies above, but it is still not optimal so it needs to be fully supported by the local government, stakeholders, media and society. The long-term strategy is to carry out an operational system for the tourism industry, with input that is paying attention to the quality of tourism destinations, and then
\end{abstract}


processing it with the full assistance of the government and the output is making structured improvements so that halal tourism in Ponorogo can develop again. From the results above, it can be concluded that Halal Tourism in Ponorogo has made improvements with the strategies above, but it is still not optimal so it needs to be fully supported by the local government, stakeholders, media and society. The longterm strategy is to carry out an operational system for the tourism industry, with input that is paying attention to the quality of tourism destinations, and then processing it with the full assistance of the government and the output is making structured improvements so that halal tourism in Ponorogo can develop again. From the results above, it can be concluded that Halal Tourism in Ponorogo has made improvements with the strategies above, but it is still not optimal so it needs to be fully supported by the local government, stakeholders, media and society. and then it is processed with the full assistance of the government and the output is structured so that halal tourism in Ponorogo can develop again. From the results above, it can be concluded that Halal Tourism in Ponorogo has made improvements with the strategies above, but it is still not optimal so it needs to be fully supported by the local government, stakeholders, media and society. and then it is processed with the full assistance of the government and the output is structured so that halal tourism in Ponorogo can develop again. From the results above, it can be concluded that Halal Tourism in Ponorogo has made improvements with the strategies above, but it is still not optimal so it needs to be fully supported by the local government, stakeholders, media and society.

Keywords: halal tourism, CHSE, pandemic, Covid-19

\section{PENDAHULUAN}

Pariwisata merupakan sektor yang memiliki peran dalam pembangunan ekonomi di Indonesia. Kemakmuran dan kesejahteraan warga negaranya menjadikan pariwisata sebagai bagian kebutuhan pokok atau gaya hidup. Sehingga secara langsung pola hidup manusia mempengaruhi mata rantai perekonomian yang silang bersinambung menjadi industri jasa yang dapat memberikan konstribusi bagi keperekonomian global, nasional dam dan meningkatkan kesejahteraan di masyarakat daerah. Data kementerian Pariwisata dan Ekonomi kreatif pada tahun 2014 menjelaskan bahwa industri pariwisata nasional mengalami lonjakan yang cukup signifikan terhadap perekonomian nasional.

Sektor pariwisata mengalami pertumbuhan mulai tahun 2015-2018 mencapai $67 \%$, hal ini ditandai dengan pertumbuhan wisata asing yang dating sejak 2014 yang berjumlah 9,7 juta hingga pada tahun 2018 menjadi 16,5 juta (IAEI, 2020). Pariwisata memberikan kontribusi yang semula $10 \%$ menjadi $17 \%$ terhadap total ekspor barang dan jasa serta posisinya sebagai penyumbang devisa terbesar sebesar 10 Miliar USD. sementara itu kontribusi secara langsung terhadap PDB dan penyerapan tenaga kerja di sektor pariwisata telah mencapai 10.18 Juta orang (Suherlan, 2015).

Hakikatnya pariwisata bisa diartikan dengan proses perjalanan sementara dari suatu tempat ke suatu tempat dalam periode dan untuk tujuan tertentu baik oleh 
perorangan maupun secara berkelompok. Pariwisata merupakan kegiatan yang melakukan perjalanam dari tempat tinggal ke tempat tujuan (Nurdin, 2019). Sementara itu menurut kamus bahasa Indonesia, wisata adalah kegiatan perjalanan secara bersama-sama yang bertujuan untuk menghibur diri, melepas penat, penyegaran kembali (refreshing), menambah wawasan, piknik dan lain-lain.

Pariwisata halal (halal tourism) merupakan salah satu pemenuh gaya hidup saat ini dimana telah menjadi kekuatan pariwisata dunia yang berkembang pesat. Pariwisata halal dipandang sebagai salah satu cara untuk mengembangkan pariwisata Indonesia yang menjunjung tinggi budaya dan nilai-nilai keislaman. Sebelum adanya pariwisata halal, masyarakat Indonesia sudah menjalani wisata syariah yang diimplementasikan dengan melakukan wisata ke kuburan (ziarah) ataupun ke masjid. padahal wisata syariah bisa diartikan lebih dari itu dengan melakukan wisata yang didalam berasal dari alam, budaya, ataupun buatan yang dibingkai dengan nilai-nilai islami (Andriani et al., 2015).

Perkembangan Pariwisata Halal Indonesia merupakan prioritas Kementrian Pariwisata dan telah memberikan hasil yang cukup menggembirakan. Pemerintah fokus terhadap pengembangan 10 Destinasi Halal Prioritas Nasional tahun 2018 antara lain: Lombok Nusa Tenggara Barat (NTB), Aceh, Riau dan kepulauan Riau, DKI Jakarta, Sumatera Barat, Jawa Barat, Jawa Tengah, Yogyakarta, Jawa Timur dan Sulawesi selatan. Berdasarkan Data GMTI (Global Muslim Travel Index) 2019 menunjukkan pertumbuhan pasar pariwisata halal Indonesia di tahun 2018 mencapai 2,8juta wisatawan muslin dengan capaian devisa lebih dari Rp. 40 triliun (Siaran Pers Kementrian Pariwisata Republik Indonesia, 2019).

Pariwisata halal di Jawa Timur masih cukup rendah pratisipasinya meskipun tempat-tempat wisata memiliki potensi untuk dikembangkan. (Setiyono et al., 2021). Potensi wisata alam dan budaya di Jawa Timur sangatlah banyak dan beragam. berbagai atraksi budaya yang mencirikan adat dan istiadat masyarakat Jawa Timur sarat akan nilai-nilai kearifan loka yang bersumber dari lelulur, serta budaya alam Jawa Timur yang menjadi daya tarik tersendiri bagi wisatawan. Hal ini juga tercermin pada pariwisata budaya dan alam di kota Ponorogo yang memiliki wisata alam seperti wisata telaga Ngebel dan wisata budaya alam seperti grebeg suro.

Pandemi Covid-19 memberikan dampak yang sangat masif dalam sendi kehidupan. Dalam sektor pariwisata merupakan sektor yang paling terimbas, dimana terjadi penurunan output karena penurunan jumlah wisatawan lokal dan mancanegara, dimana terjadi pembatalan kegiatan wisata (Anggarini, 2021). Hal ini tercermin juga 
terhadap pariwisata halal di kota ponorogo, dimana destinasi wisata alam ditutup dan wisata budaya dihentikan. Kegiatan wisata alam ditutup ketika terjadi pembatasan berskala nasional ataupun daerah. Kegiatan wisata budaya seperti grebek suro 2020 telah dihentikan dengan mempertimbangkan untuk mencegah potensi penularan Covid-19 (Pemkab Ponorogo, 2020).

Sebagai Upaya mengatasi dampak Covid-19 terhadap sektor pariwisata halal, pemerintah memberlalukan kebijakan kenormalan baru (new normal). Dimasa transisi kenormalan baru, pemerintah telah menyiapkan beberapa strategi untuk memulihkan sektor pariwisata. Pemerintahan Kabupaten Ponorogo juga telah merencanakan upaya-upaya untuk mendongkrak kembali sektor pariwisata yang didukung oleh kementrian pariwisata dengan melakukan penerapan prokes dalam bidang serifikasi CHSE yaitu Cleanliness (Kebersihan), Health (Kesehatan), Safety (Keamanan), dan Environment Sustainability (Ramah lingkungan) (RRI, 2021).

Beberapa studi sebelumnya tentang pengembangan pariwisata halal di Ponorogo, misalnya penelitian yang dilakukan oleh Ika susilawati (Wati, 2020) menjelaskan bahwa persepsi masyarakat terhadap telah siap terhapap pengembangan pariwisata di kota Ponorogo mengalami peningkatan assebilitas, akomodasi dadukungan pemerentah daerah, hal ini juga didukung dengan ketersediaan makanan halal. Menurut setiyono et. al (2020) menjelaskan bahwa Objek wisata telaga ngebel yang merupakan salah satu destinasi pariwisata halal di Ponorogo telah memiliki kesiapan penerapan pariwisata halal. Kemudian studi tentang pemulihan pontensi pariwisata pada masa pandemik, misalnya menurut solemede et. al (2020) potensi pemulihan pariwisata di kota Maluku sangatlah memungkinkan namun perlu didukung peran aktif dari pemerintah daerah dan melibatkan seluruh sektor pariwisata. Kemudian menurut anggarini (2021) upaya pemulihan sektor pariwisata dengan meningkatkan penerapan 'CHSE' alias Cleanliness (Kebersihan), Health (Kesehatan), Safety (Keamanan), dan Enviroment (Ramah lingkungan).

Namun studi potensi pemulihan pariwisata halal di kabupaten Ponorogo pada masa pandemi Covid-19 masih belum ada sehingga masih perlu dilakukan penelitian lebih lanjut. Studi ini akan mencoba menggali potensi upaya pemulihan pariwisata halal dengan pendekatan analisa deskriptif. Secara khusus, tujuan dari penelitian ini adalah melakukan analisa strategi pemulihan potensi pariwisata halal di Ponorogo pada masa pandemi Covid-19. 


\section{TINJAUAN LITERATUR}

\section{Pariwisata Halal}

Pertumbuhan jumlah penduduk muslim menciptakan pasar wisatawan muslim sehingga mendorong potensi perkembangan pariwisata halal di Indonesia. Menurut Battaour dan Ismali dalam Setiyono et al (2021) bahwa meningkatnya minat muslim dalam melakukan wisata mendorong praktisi dan peneliti untuk mengembangkan dan memasarkan pariwisata yang memiliki fasilitas ramah muslim berdasarkan prinsip syariah Menutur Fatwa MUI Nomor 108/DSN-MUI/X/2016 pengertian wisata halal adalah wisata yang sesuai dengan prinsip syariah (syariat Islam). Prinsip-prinisp nilai syariah islam, baik mulai dari niatnya dan tidak melanggar yang bertentangan dengan syariah, serta makan dan minum yang halalan thayyian. Prinsip-prinsip pengembangan wisata berbasis syariah diantaranya mencangkup pengembangan fasilitas wisata syariah berada dalam lingkup tempat wisata, fasilitas dan pelayanan berbasis syariah dilakukan oleh warga sekitar, pengembangan wisata syariah harus sesuai dengan nilai-nilai luhur serta kearifan lokal budaya setempat yang masih berlaku (Noviantoro \& Zurohman, 2020).

Perbedaan antara wisata konvensional, wisata dan wisata halal dapat dilihat pada table berikut ini:

\section{Tabel 1}

Perbedaan Antara Wisata Konvensional, Wisata Religi dan Wisata Syariah

\begin{tabular}{|c|c|c|c|c|}
\hline No & $\begin{array}{l}\text { Item } \\
\text { Perbandingan }\end{array}$ & Konvensional & Wisata Religi & Wisata Syariah \\
\hline 1 & Objek & $\begin{array}{l}\text { Alam, budaya, } \\
\text { heritage, kuliner }\end{array}$ & $\begin{array}{l}\text { Tempat ibadah, } \\
\text { peninggalan sejarah }\end{array}$ & Semua \\
\hline 2 & Tujuan & Menghibur & $\begin{array}{l}\text { Meningkatkan } \\
\text { spiritualitas }\end{array}$ & $\begin{array}{l}\text { Meningkatkan } \\
\text { spirit religiusitas } \\
\text { dengan cara } \\
\text { menghibur }\end{array}$ \\
\hline 3 & Target & $\begin{array}{l}\text { Menyentuh } \\
\text { Kesenangan }\end{array}$ & $\begin{array}{l}\text { Aspek spiritualitas } \\
\text { yang bisa } \\
\text { menenangkan jiwa, } \\
\text { semata-mata mencari } \\
\text { ketenangan batin }\end{array}$ & $\begin{array}{l}\text { Memenuhi } \\
\text { Keinginan dan } \\
\text { menumbuhkan } \\
\text { kesadaran } \\
\text { beragama }\end{array}$ \\
\hline
\end{tabular}




\begin{tabular}{|c|c|c|c|c|}
\hline No & $\begin{array}{l}\text { Item } \\
\text { Perbandingan }\end{array}$ & Konvensional & Wisata Religi & Wisata Syariah \\
\hline 4 & Guide & $\begin{array}{l}\text { Memahami dan } \\
\text { menguasai } \\
\text { informasi, sehingga } \\
\text { bisa menarik } \\
\text { wisatawan ke } \\
\text { obyek } \\
\text { wisata }\end{array}$ & $\begin{array}{l}\text { Menguasai sejarah } \\
\text { tokoh dan lokasi } \\
\text { tempat wisata }\end{array}$ & $\begin{array}{l}\text { Membuat } \\
\text { wisatawan } \\
\text { tertarik } \\
\text { pada obyek } \\
\text { sekaligus } \\
\text { membangkitkan } \\
\text { spirit religiuitas } \\
\text { wisatawan }\end{array}$ \\
\hline 5 & $\begin{array}{l}\text { Fasilitas } \\
\text { Ibadah }\end{array}$ & Sekedar pelengkap & Sekedar pelengkap & $\begin{array}{l}\text { Menjadi } \\
\text { bagian } \\
\text { yang menyatu } \\
\text { dengan obyek } \\
\text { wisata, ritual } \\
\text { ibadah menjadi } \\
\text { paket hiburan } \\
\text { wisata }\end{array}$ \\
\hline 6 & Kuliner & Umum & Umum & $\begin{array}{l}\text { Spesifik yang } \\
\text { halal }\end{array}$ \\
\hline 7 & $\begin{array}{l}\text { Relasi dengan } \\
\text { masyarakat di } \\
\text { lingkungan } \\
\text { objek } \\
\text { wisata }\end{array}$ & $\begin{array}{l}\text { Komplementer dan } \\
\text { semata-mata } \\
\text { mengejar } \\
\text { keuntungan }\end{array}$ & $\begin{array}{l}\text { Komplementer dan } \\
\text { semata-mata } \\
\text { mengejar } \\
\text { keuntungan }\end{array}$ & $\begin{array}{l}\text { Interaksi } \\
\text { berdasar } \\
\text { pada prinsip- } \\
\text { prinsip syariah }\end{array}$ \\
\hline 8 & $\begin{array}{l}\text { Agenda } \\
\text { perjalanan }\end{array}$ & $\begin{array}{l}\text { Mengabaikan } \\
\text { waktu }\end{array}$ & Peduli perjalanan & $\begin{array}{l}\text { Memperhatikan } \\
\text { waktu }\end{array}$ \\
\hline
\end{tabular}

Sumber: Dini andriani, et al Laporan awal kajian pengembangan wisata syari'ah' Jakarta: Kementrian Pariwisata RI. 2015.

\section{Potensi Pariwisata Halal}

Republik Indonesia merupakan negara muslim terbesar di dunia dengan jumlah penduduk muslim lebih dari 229 juta orang. Indonesia juga merupakan Negara kepulauan terbesar yang memiliki potensi wisata alam. Hal ini merupakan potensi pariwisata yang dapat dikembangkan. selain itu Indonesia juga memiliki warisan budaya dan agama dengan keragaman suku, etnis, bahasa dan adat istiadat. Dengan besarnya potensi yang dimiliki menjadikan sektor pariwisata akan semakin 
berkembang di masa depan dan salah satu potensi pariwisata yang menjadi daya tarik adalah pariwisata halal.

Pentingnya potensi pariwisata halal dimulai disampaikan oleh mantan Presiden SBY pada saat peluncuran Gerakan Ekonomi Syariah (GRES) pada tahun 2013. Pada kesempatan itu presiden SBY menjelaskan bahwa pemerintah mulai mengembangkan wisata syariah dengan mempersiapkan 13 (tiga belas) provinsi untuk dijadikan destinasi wisata syariah. Pada tahun 2019, Pemerintahan Presiden Joko Widodo, wisata halal telah mencapai keberhasilan dengan mengembangkan pariwisata halal sehingga Indonesia menempati peringkat peratas MastercardCrescent Rating Global Muslim Travel Index (GMTI) 2019.

Potensi pasar wisata halal merupakan salah satu sektor pariwisata dengan pertumbuhan tercepat di dunia, dan tentu saja di Indonesia. Pasar pariwisata halal ini telah melalui perubahan yang cukup signifikan, dimulai dengan para pelaku usaha menyediakan layanan-layanan sesuai kebutuhan wisatawan muslim, seperti makanan halal, toilet yang menyediakan air bersih dan fasilitas ibadah (republika.co.id, 2019). Tetapi terlepas dari potensinya yang besar, sektor ini masih relative masih belum dikembangkan secara maksimal ditambah dengan adanya pandemi Covid-19 menjadikan tantangan baru pada pengembangan pariwisata halal.

\section{Kenormalan Baru (New Normal) Pariwisata.}

Kementrian Pariwisata dan Ekonomi Kreatif pada siaran persnya pada tanggal 29 Mei 2020 menyampaikan bahwa persiapan protokol kenormalan baru pariwisata setalah disusun dan siap diimplementasikan. Protokol kenormalan baru pariwisata terdiri dari beberapa tahapan dimulai dari melakukan simulasi, sosialisasi dan publikasi kepada publik. Dalam pelaksanaannya tahapan-tahapan ini akan diawasi dengan ketat dan mempertimbangkan kesiapan daerah (IAEI, 2020). Protokol kesehatan berbasis CHSE yaitu Cleanliness (Kebersihan), Health (Kesehatan), Safety (Keamanan), dan Enviroment (Ramah lingkungan) merupakan protokol kenormalan baru pariwisata.

Strategi penerapan protokol CHSE mengacu pada keputusan Menteri Kesehatan No. HK.01.07/Menkes/382/2020 dan World Healthy Organization (WHO). Sertifikasi CHSE merupakan sertifikasi kepada usaha pariwisata, destinasi pariwisata dan produk pariwisata lainnya untuk memberikan jaminan kepada wisatawan terhadap pelaksanaan kebersihan, kesehatan, keselamatan dan kelestarian lingkungan di masa pandemi. (Kementerian Pariwisata dan Ekonomi Kreatif, 2020). 
Pada penerapan CHSE pelaku usaha pariwisata untuk mendapatkan verifikasi dan sertifikasi untuk penerapan protokol CHSE pada usahanya.

Tahapan verifikasi dan sertifikasi CHSE:

1. Tahap Penyusunan; Kolaborasi pemerintah menyusun protokol kesehatan berbasis CHSE;

2. Tahap Implementasi; Sosialisasi protokol kesehatan berbasis CHSE ke Daerah;

3. Tahap Pemantauan; peninjauan dan penilaian CHSE terhadap Industri Pariwisata yang akan terdaftar sesuai dengan kriteria yang ditentukan.

Presiden Republik Indonesia memberikan arahan kepada kementrian pariwisata untuk melakukan inovasi dan perbaikan pada sektor pariwisata, diharapkan dengan adanya perubahan tren pariwisata pada masa pandemi pariwisata Indonesia mampu beradaptasi. Perubahan tren wisata bergeser pada alternatif wisata yang tidak bertemu dengan banyak orang, dimana isu health, hygiene dan safety akan menjadi pertimbangan utama bagi wisatawan untuk menentukan destinasinya (Solemede et al., 2020).

Selain menggunakan pendekatan penerapan CHSE, namun pemulihan strategi pemulihan destinasi pariwisata dapat digolongkan menjadi 3, yaitu

1. Strategi jangka pendek yaitu strategi ini dapat dilakukan dengan dukungan dari pemerintah daerah, mulai dari dukungan finansial, sampai kebijakan yang dikeluarkan oleh pemerintah setempat

2. Strategi jangka menengah yaitu strategi ini dapat diterapkan dengan menggunakan strategi penthahelik yaitu dengan mencampurkan academic, business, government customer and media (ABGCM)

3. Strategi jangka panjang yaitu strategi ini dapat dilakukan dengan mengatur sebuah system operational industry pariwisata yaitu dari input, proses, output dan outcome. ( Desak \& Made, 2021).

\section{METODE PENELITIAN}

Metode penelitian yang digunakan dalam penelitian ini adalah penelitian kualitatif dengan pendekatan deskriptif. Menurut bogdam dan Taylor (1975) dalam Moeloeng (2014) mendefinisikan penelitian kualitatif sebagai proses penelitian deskriptif yang menghasilkan data berupa kata-kata tertulis maupun lisan dari pelaku yang bisa diamati. Dengan pengertian tersebut, peneltian ini bertujuan untuk menjelaskan dan menggambarkan secara mendalam tentang strategi pemulihan potensi wisata di kabupaten Ponorogo. Proses penelitiannya dengan cara 
mengumpulkan data, menyusun dan mengklarifikasikan, menyusun dan menginterpretasikannya.

Dalam teknik pengumpulan data, peneliti menggunakan triangualsi berupa observasi, wawancara dan dokumentasi, penulis melakukan observasi terhadap beberapa destinasi wisata di Ponorogo, melakukan wawancara dengan pegiat wisata di sana dan mengidentifikasi dokumentasi berupa wacana dari buku-buku, makalah atau artikel, majalah, jurnal, website ataupun informasi lainnya yang berhubungan dengan judul penulisan untuk mencari hal-hal atau variable yang berupa catatan, transkip, buku, surat kabar, majalah ataupun website yang berkaitan dengan potensi pemulihan pariwisata halal di Ponorogo dengan menganalisa strategi pemulihan potensi pariwisata halal di Ponorogo pada masa pandemi Covid-19.

\section{HASIL DAN PEMBAHASAN}

Ponorogo adalah sebuah kabupaten di Jawa Timur dengan potensi wisata yang luar biasa, kekayaan pariwisata kabupaten Ponorogo beraneka ragam, dari mulai wisata religi, kuliner hingga wisata alam. Tersebut ada sekitar 50 titik potensi destinasi wisata yang ada di Ponorogo dengan peningkatan wisatawan sebanyak $2 \%$ pada setiap tahunnya, rincian destinasi wisata di ponorogo meliputi 31 wisata alam, 9 wisata religi dan sejarah, serta 10 wisata buatan.

Wisata alam ponorogo sangat menawan, terbukti daerah ini pernah menyabet anugerah wisata jawa timur pada tahun 2018 yang semakin membuat pemerintah daerah semangat dalam membangun sektor wisata. Perhatian pemerintah daerah Ponorogo terhadap pembangunan sektor pariwisatanya dapat dilihat dari salah satu misi pemerintah daerah yaitu pengelolaan seluruh potensi sumber daya yang ada menjadi lebih unggul, berdaya guna, produktif, berkelanjutan, serta menjadi bermanfaat secara luas.

Namun, setelah adanya ketetapan WHO mengenai virus COVID 19 menjadi pandemic yang menyerang seluruh dunia menyebabkan hampir lumpuhnya segala sektor kehidupan manusia. Salah satu sektor yang paling terpuruk adalah sektor pariwisata, sebab masyarakat dilarang untuk keluar rumah demi terhindar dari virus mematikan, padahal destinasi pariwisata membutuhkan kunjungan untuk operasionalnya. Selain itu, dampak pun dirasakan oleh semua pegiat pariwisata, baik itu pedagang, penyewa penginapan sampai penyedia transportasi, ketiadaan pengunjung membuat sebagian dari mereka gulung tikar. 
Sekitar satu tahun berlalu, Virus Covid-19 mulai sedikit mereda, masyarakat diminta terbiasa untuk menjalani tatanan hidup baru (new normal). Dalam tantaan kehidupan yang baru (new normal), masyarakat tetap bisa melakukan aktivitas seperti biasa, tetapi dengan menjaga protocol kesehatan secara ketat. Begitu pula dengan sektor pariwisata, meskipun masih terseok-seok, tetapi masih tetap bisa berjalan sedikit demi sedkit, semenjak diperbolehkan lagi mengunjungi destinasi wisata oleh pemerintah daerah, Pemulihan kembali potensi pariwisata perlu dilakukan tidak hanya oleh pemerintah daerah, tetapi juga kontribusi dari setempat.

Kenormalan baru (New Normal) pariwisata dimulai dengan pengimplemetasian protokol kesehatan berbasis CHSE Cleanliness (Kebersihan), Health (Kesehatan), Safety (Keamanan), dan Enviroment (Ramah lingkungan). Dalam hal ini pemerintah Kabupaten ponorogo telah menungkannya pada Surat Edaran Bupati Ponorogo Nomor: 713/3558/405.01.3/2020 Tentang Penerapan Protokol Kesehatan pada Kegiatan Bidang Pendidikan, Kebudayaan dan Kepariwisataan di Kabupaten Ponorogo. Berdasarkan surat edaran tersebut:

1. Menurut Point 5 tentang pembatasan penggunaan akomodasi hotel atau peginapan, dengan ketentuan sebagai berikut:

a. Membatasi maksimal 50\% (lima puluh persen) dari kapasitas yang tersedia

b. meniadakan kegiatan hiburan yang menyebabkan kerumunan masyarakat didalam atau diluar ruangan

c. terhadap fasilitas lainnya seperti, ruang pertemuan, ruang olah raga dan restoran maksimal 50\% (lima puluh persen) dan kolam renang harus ditutup.

d. Memperlakukan protokol kesehatan yang cukup ketat, yaitu:

$\checkmark$ menggunakan masker

$\checkmark$ mejaga jarak

$\checkmark$ mencuci tangan pakai sabun dengan air mengalir

$\checkmark$ melakukan pemgukuran suhu badan secara ketat.

2. Menurut poin 6, melakukan pembatasan jam kegiatan operasional terhadap kafe, restoran dan/atau sejeninsnya serta Pedagang kaki lima (PKL) diseputaran jalan di seluruh wilayah Kabupaten Ponorogo sampai dengan pikil 21.00

3. Menurut point 12 yaitu nelakukan sosialisasi mengenai surat edaran kepada seluruh pihak yang terkait dan masyarakat.

4. Menurut point 13 yaitu tim gabungan Satgas Covid-19 melakukan pengawasan dan memberikan peringatan dan/atau penindakan terhadap pelanggaran ketentuan protokol kesehatan. 
Berdasarkan surat diatas dapat disimpulakan implementasi dari protokol CHSE sudah dilaksanakan oleh pelaku pariwisata, namun bentuk sertifikasinya yang masih perlu menjadi perhatian oleh pemerintah daerah Kabupaten Ponorogo. Menurut Desak \& Made (2021, p. 88-94) strategi pemulihan destinasi pariwisata dapat digolongkan menjadi 3, yaitu 1) Strategi jangka pendek, 2) Startegi jangka menengah 3). Strategi jangka panjang, berikut adalah macam-macam strategi yang diterapkan oleh pemerintah daerah kabupaten Ponorogo.

1. Strategi jangka pendek

Strategi ini dapat dilakukan dengan dukungan dari pemerintah daerah, mulai dari dukungan finansial, sampai kebijakan yang dikeluarkan oleh pemerintah setempat. Pemerintah daerah kabupaten Ponorogo mulai membuka kembali destinasi pariwisata pada masa normalisasi baru (new normal) dengan menerapkan protocol yang ketat, menjaga kebersihan dan kesehatan di wilayah destinasi. Dukungan finansial pun tidak kalah penting, dukungan pemerintah daerah terhadap sektor pariwisata dengan porsi kebijakan anggaran yang cukup tinggi dalam APBD pada 2016, 2017, dan 2018, mulai menambah fasilitasfasilitas umum di destinasi wsiata serta alat- alat kesenian yang dibagikan kepadaa paguyuban-paguyuban kesenian.

2. Strategi jangka menengah

Strategi ini dapat diterapkan dengan menggunakan strategi penthahelik yaitu dengan mencampurkan academic, business, government customer and media (ABGCM).

a. Peran Lembaga Pendidikan

Kabupaten Ponorogo terkenal dengan sebutan kota santri, banyak pondok pesantren dan lembaga sekolah Islam berada di sini. Tidak hanya itu, perguruan tinggi pun banyak berdiri di kawasan ini, mulau dari lembaga perguruan tinggi negeri hingga swasta. Peran lembaga pendidikan dalam kemajuan destinasi pariwisata adalah dengan memberikan eksposure kepada para siswa/ mahasiswa tentang profile destinasi wisata di Ponorogo, mulai dari sejarahnya, lokasinya hingga kelebihan destinasi wisata tersebut. Ekposure tentang destinasi pariwisata bisa dari pembuatan materi pembelajaran dengan konten suatu destinasi wisata, atau tugas serta aktivitas yang melibatkan siswa untuk menerangkan atau mengalanisis tentang suatu objek wisata. 
b. Peran pemerintah

Peran pemerintah dalam mempromosikan potensi suatu destinasi wisata dapat dilakukan dengan melibatkan media dan suatu komunitas. Pelibatan media sangat efektif dilakukan pada era digital dan masa pandemic seperti saat ini, salah satu media favourite bagi masyarakat saat ini adalah instagram, promosi perkembangan kabupaten Ponorogo dapat dengan mudah diakses oleh khayalak ramai, terlebih jika menggandeng suatu komunitas yang punya pengaruh kuat, maka sosialisasi suatu kebijakan pariwisata akan lebih cepat tersampaikan.

3. Strategi jangka panjang

Strategi ini dapat dilakukan dengan mengatur sebuah system operational industry pariwisata yaitu dari input, proses, output dan outcome (Desak \& Made, 2021).

a. Pembenahan sisi input dapat dilakukan dengan memperhatikan suatu kualitas destinasi wisata, seperti kualitas sumber daya manusia serta kualitas lokasi wisata. Kualitas sumber daya manusia dapat dilakukan dengan meningkatkan kualitas kompetensi individu yang bergerak pada bidang pariwisata, contohnya peningkatan pelatihan kepada pekerja pariwisata rhadap pengunjung wisata, para pegawai di destinasi pariwisata di Ponorogo sudah baik dalam melayani pengunjung.

b. Pembenahan sisi proses dapat dilakukan dengan bantuan pemerintah daerah dalam meningkatkan kualitas internal dan eksternal suat wisata. Kualitas internal dapat berupa perlakuan baik bagi para pekerja, lalu kualitas ekesternal dapat erupa penyediaan pelayanan bagi wisatawan. Selain itu, peningkatan kualitas lokasi wisata pun perlu dilakukan, salah satunya dengan cara meningkatkan aspek keamanan dan kenyamanan.

c. Pembenahan sisi output akan dihasilkan jika sudah benar memperbaiki sisi input dan proses. Hasilnya, loyalitas dan kepuasan konsumen pun akan didapat.

d. Pembenahan sisi outcome adalah hasil lanjutan dari pembenahan sisi output, jika konsumen sudah puas dan menjadi loyal terhadap suatu destinasi wisata, maka mereka akan berpikir untuk mengunjungi suatu wisata tersebut. 


\section{KESIMPULAN}

Kabupaten Ponorogo merupakan salah satu kabupaten di Jawa timur yang bisa diperhitungkan sebagai tujuan wisata, mengingat potensi wisata di sana sangat bagus dengan pelayanan yang ramah dan tingkat kriminalitas yang rendah. Kekayaan pariwisata kabupaten Ponorogo beraneka ragam, dari mulai wisata religi, kuliner hingga wisata alam. Tersebut ada sekitar 50 titik potensi destinasi wisata yang ada di Ponorogo dengan peningkatan wisatawan sebanyak $2 \%$ pada setiap tahunnya, rincian destinasi wisata di ponorogo meliputi 31 wisata alam, 9 wisata religi dan sejarah, serta 10 wisata buatan.

Namun, kegiatan pariwisata menurun drastis bahkan nyaris behenti ketika dunia dilanda virus Covid 19, pemerintah Indoensia meminta masyarakatnya untuk menjaga diri dengan tetap di rumah dan mengurangi kontak fisik dengan manusia lain agar tidak tertular virus tersebut. Keadaan seperti ini tentu merugikan pegiat pariwisata karena banyak usaha yang lesu hingga akhirnya gulung tikar.

Setelah new normal, berbagai destinasi pariwisata pun dibuka kembali, berbagai strategi dilakukan untuk menarik para wisatwan kembali, diantaranya dengan pengaturan strategi jangka pendek, jangka menengan dan jangka panjang.

\section{REFERENSI}

Siaran Pers Kementrian Pariwisata Republik Indonesia . 2019. "5 Tahun Kembangkan Pariwisata Halal, Indonesia Akhirnya Raih Peringkat Pertama Wisata Halal Dunia 2019",

https://kominfo.go.id/content/detail/18069/5-tahun-kembangkan-pariwisatahalal-indonesia-akhirnya-raih-peringkat-pertama-wisata-halal-dunia2019/0/artikel_gpr

Andriani, D., Khalik, K., A., \& Nurhayati, T. (2015). Kajian Pengembangan Wisata Syariah. Asdep Litbang Kebijakan Kepariwisataan, Syariah Tourism, 1-201. http://www.kemenpar.go.id/userfiles/2015 Kajian Pengembangan Wisata Syariah.pdf

Anggarini, D. T. (2021). Upaya Pemulihan Industri Pariwisata Dalam Situasi Pandemi Covid -19. Jurnal Pariwisata, 8(1), 22-31. https://doi.org/10.31294/par.v8i1.9809

IAEI. (2020). Laporan Perkembangan Pariwisata Ramah Muslim Daerah. Komite Nasional Ekonomi Dan Keuangan Syariah (KNEKS), 72 pages.

Pemerintah Daerah Ponorogo (2020). Surat Edaran Bupati Ponorogo Nomor: 
713/3558/405.01.3/2020 Tentang Penerapan Protokol Kesehatan Pada Kegiatan Bidang Pendidikan, Kebudayaan Dan Kepariwisataan Di Kabupaten Ponorogo

Dinas Pariwisata Kabupaten Ponorogo, "Potensi Pariwisata Kabupaten Ponorogo Tahun 2016," Ponorogo, 2016.

Kementerian Pariwisata dan Ekonomi Kreatif, R. I. (2020). Panduan Pelaksanaan Kelestarian Lingkungan di Daya Tarik Wisata Panduan Pelaksanaan Kelestarian Lingkungan di Daya Tarik Wisata. Edisi Agus, 72.

Kominfo Pemkab Ponorogo. 2020. “ Ditengah Pandemi Covid-19. Festival Nasional Reyog Ponorogo ditiadakan" https://ponorogo.go.id/2020/07/02/ditengah-pandemi-covid-19-festivalnasional-reyog-ponorogo-ditiadakan/

Noviantoro, K. M., \& Zurohman, A. (2020). Prospek Pariwisata Syariah (Halal Tourism): Sebuah Tantangan di Era Revolusi Industri 4.0. Equilibrium: Jurnal Ekonomi Syariah, 8(2), 275. https://doi.org/10.21043/equilibrium.v8i2.8160

Setiyono, A., Rusli, L., Maulana, H., \& Astuti, R. Y. (2021). Sikap Pelaku Pariwisata terhadap Potensi Wisata Syariah di Obyek Wisata Telaga Ngebel Ponorogo. Journal of Management and Business Review, 18(1), 77-88. https://doi.org/10.34149/jmbr.v18i1.238

Solemede, I., Tamaneha, T., Selfanay, R., Solemede, M., \& Walunaman, K. (2020). STRATEGI PEMULIHAN POTENSI PARIWISATA BUDAYA DI PROVINSI MALUKU ( Suatu Kajian Analisis di Masa Transisi Kenormalan Baru ). Jurnal Ilmu Sosial Keagamaan, I(1), 69-86.

Suciati, Desak \& Suadnya, I. (2021) Strategi Pemulihan Pariwisata Pasca Penanganan Pandemi COVID 19 di Provinsi Bali.Jurnal Penerangan Agama, Pariwisata Budaya, dan ilmu Komunikasi, I(1), 88-94.

Suherlan, A. (2015). Persepsi Masyarakat Jakarta Terhadap Islamic Tourism. The Journal of Tauhidinomics, 1(1), 61-72.

Wati, I. S. (2020). Strategi Pengembangan Bisnis Wisata Syariah Pada Masyarakat Pluralis di Kabupaten Ponorogo. In International Journal Ihya' 'Ulum al-Din (Vol. 22, Issue 1, p. 97). https://doi.org/10.21580/ihya.22.1.5594

RRI, 2021. "Jurus Sandiaga Uno bangkitkan Pariwisata Ponorogo" https://rri.co.id/humaniora/wisata/1080472/jurus-sandiaga-uno-bangkitkanpariwisata-ponorogo

Republika, 2019. “ Indonesia peringkat pertama global muslim idex 